\title{
CASE REPORT-NASO-ETHMOIDAL ENCEPHALOCELE
}

Shrishail Patil ${ }^{1}$, Tanvi Choubey ${ }^{2}$

\section{HOW TO CITE THIS ARTICLE:}

Shrishail Patil, Tanvi Choubey. "Case Report-_Naso-ethmoidal Encephalocele". Journal of Evolution of Medical and Dental Sciences 2014; Vol. 3, Issue 24, June 16; Page: 6747-6751, DOI: 10.14260/jemds/2014/2814

ABSTRACT: A rare case of 5yrs old boy came with chief complaint of swelling at nasal bridge since birth. It was gradually increasing in size, with recurrent attacks of cold. No history of trauma or fever. Radiograph of PNS shows opacification of left nasal cavity with deviated nasal septum towards right. Patient was further evaluated with CT- PNS and MRI- Brain (3-d drive thin sections).Finally diagnosis of naso-ethmoid encephalocele was made. Patient underwent surgery and final histopathological diagnosis was nasoethmoidal encephalocele.

KEYWORDS: Encephalocele, Frontoethmoid.

INTRODUCTION: An encephalocele is a herniation of intracranial contents through a midline skull defect. Also known as cephaloceles, these lesions are classified by their contents and location. Encephaloceles usually are located in the occipital (75 percent) or frontal areas (25 percent).

Basal and trans-sphenoidal encephaloceles are rare; they may appear between the ethmoid and sphenoid bones and extend into the upper pharynx. Encephaloceles that extend from the area of the orbit, nose or forehead are termed sincipital encephaloceles.\{1\}

CASE SUMMARY: 5 yrs old boy came with chief complains of swelling at nasal bridge since birth with recurrent attacks of cold frequently. Patient was referred to radiology department for evaluation. PNS Radiograph shows opacification of left nasal cavity with deviated nasal septum towards right.

NECT (3D) Revealed: Bony defect in cribriform plate and soft tissue density mass in left nasal cavity with intracranial extension, CT values $+5 \ldots+7$. HU. Nasal septum deviated towards right side. Soft tissue density areas seen in bilateral maxillary, ethmoidal, sphenoidal sinus. Evidence of non pneumatization of frontal sinus.

MRI-BRAIN and PNS revealed mass in left nasal cavity measuring:- 36X21mms in sagittal diameter and $15 \mathrm{mms}$ in transverse diameter, with small bony defect in fonticulus nasofrontalis. Lesion extending superiorly through the defect and intracranial communication was noted. No other intracranial abnormality seen.

With above mentioned findings diagnosis of nasoethmoidal encephalocele was made. Patient underwent surgery and specimen was sent for histopathology.

HISTOPATHOLOGY: Report was multiple tissue bits show round to oval cells with scant cytoplasm in a fibrullary background, with areas of glial tissues and fragments of meningothelial cells with few mixed inflammatory cells. Histomorphological features consistent with encephalocele.

DISCUSSION: Nasal encephaloceles can be divided into frontoethmoidal and basal encephaloceles. Both conditions are very rare, but frontoethmoidal encephaloceles show a relatively high incidence $(1: 5,000)$ in southeast Asia. $\{2\}$ 
The probable etiology could be:

1. Genetic component-occurring in families with spina bifida and anencephaly.

2. Teratogens $x$-ray irradiations, trifan blue, vitamin-a, arsenic etc.

The pathogenesis of encephalocele may be explained by separation of surface ectoderm and neuroectoderm in the midline just after closure of neural fold.

Nasalencephalocele can be divided into sincipital and basal variety. Sincipital form consists of naso-frontal, naso-ethmoid and naso-orbital subtypes, whereas basal form consists of transethmoidal, spheno-ethmoidal, spheno-orbital and trans-sphenoidal sub-types.\{3\}

Imaging modalities are imperative to the diagnosis of an encephalocele along with providing assistance in determining the extent of the lesion, the type of herniation and any other concomitant deformity that might be missed on physical examination. ${ }^{4\}}$

Computed tomography (CT) scan can be utilized, as it delineates bony defects very well. Magnetic resonance imaging (MRI) which complement the CT findings and is even superior to it by making vessels discernable and better illustrating intracranial communication in majority of cases.

As CT \& MRI are very useful in making a diagnosis and to differentiate it from other nasal masses like polyp, mucocele, thus avoids biopsy and helps in proper surgical management.

CONCLUSION: Nasoethmoidal encephalocele is a rare condition, and it is important to differentiate it from other nasal masses like polyps, mucoceles. Imaging plays a very important role in diagnosis of nasoethmoidal encephalocele. CT and MRI are complimentary; CT well delineates the bony defect. MRI- shows intracranial communication and contents of the herniated sac.

\section{REFERENCES:}

1. SWAIMAN PEDIATRIC NEUROLOGY ENCEPHALOCELE:- Kenneth F. Swaiman, Stephen Ashwal, Donna M. Ferriero, and Nina F. Schor, [chapter 22] 5th Edition published by Elsevier https://www.inkling.com/read/swaiman-swaimans-pediatric-neurology-5th/chapter22/encephalocele.

2. Christopher G M Richards Frontoethmoidal meningoencephalocele: a common and severe congenital abnormality in South East Asia - Archives of Disease in Childhood 1992; 67: 717-719 published by:- group.bmj.com http://adc.bmj.com/content/67/6/717.full.pdf.

3. Divyanshu Dubey, Sonjjay Pande, Pradeep Dubey, Anshudha Sawhney A Case of Naso-Ethmoidal Meningoencephalocele. Vol. 3 No. 8 (August 2011) published by: International Journal of Collaborative Research on Internal Medicine \& Public Health. http://www.iomcworld.com/ijcrimph/files/v03-n08-08.pdf

4. Montasir Junaid, Maliha Kazi, Mumtaz Jamshed Khan Nasal Encephaloceles presenting at later ages: Experience of Otorhinolaryngology [JANUARY 2012]. http://www.jpma.org.pk/full_article_text.php?article_id=3237. 


\section{CASE REPORT}
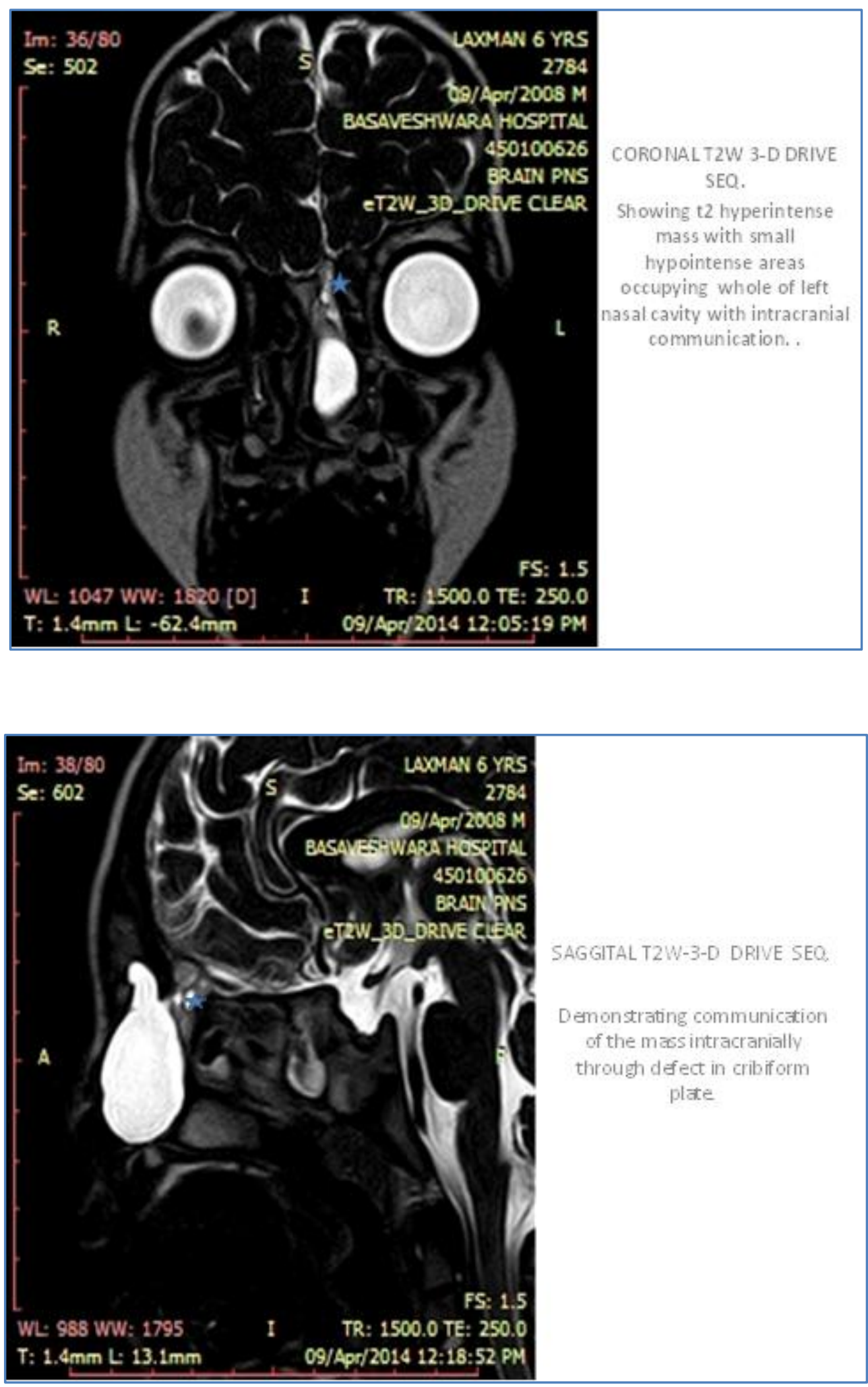

J of Evolution of Med and Dent Sci/ eISSN- 2278-4802, pISSN- 2278-4748/ Vol. 3/ Issue 24/June 16, 2014 


\section{CASE REPORT}
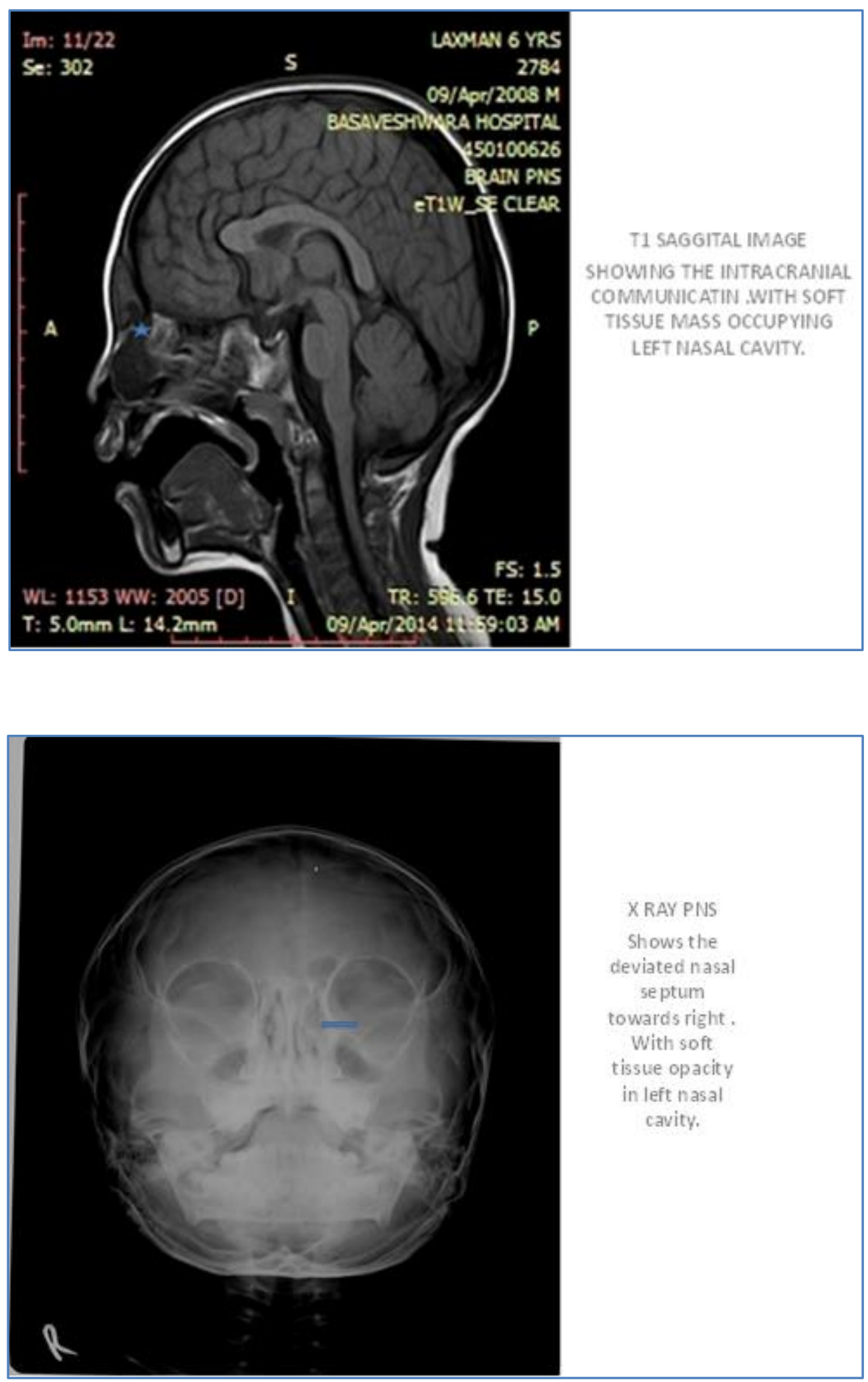

J of Evolution of Med and Dent Sci/ eISSN- 2278-4802, pISSN- 2278-4748/ Vol. 3/ Issue 24/June 16, 2014 


\section{CASE REPORT}

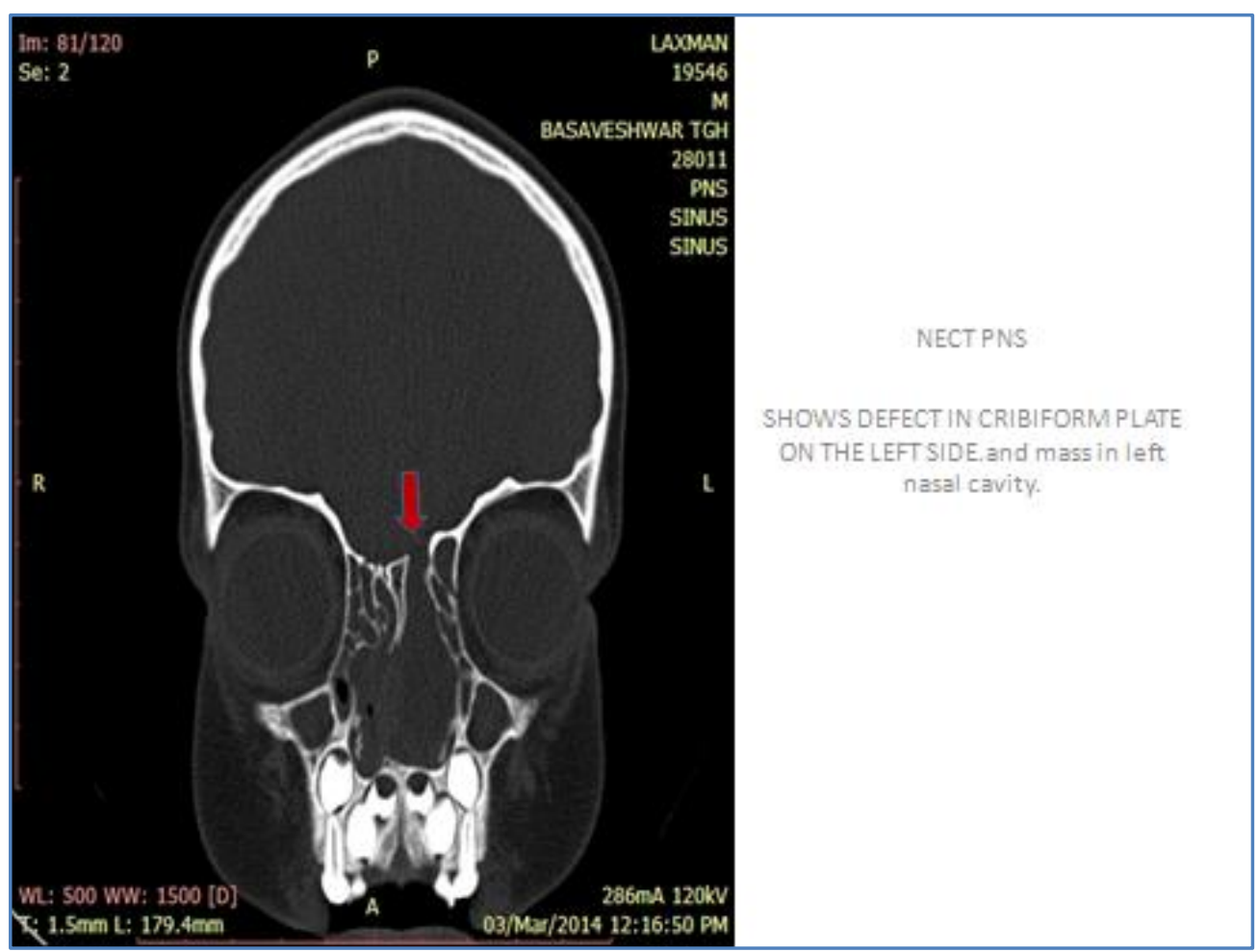

\section{AUTHORS:}

1. Shrishail Patil

2. Tanvi Choubey

\section{PARTICULARS OF CONTRIBUTORS:}

1. Associate Professor, Department of Radiodiagnosis, MRMC, Basveshwar Hospital, Gulbarga.

2. Post Graduate, Department of Radiodiagnosis, MRMC, Basveshwar Hospital, Gulbarga.

\section{NAME ADDRESS EMAIL ID OF THE} CORRESPONDING AUTHOR:

Dr. Tanvi Choubey, MRMC PG Girl's Hostle.

E-mail: kanuchoubey@gmail.com Gulbarga.

Date of Submission: 30/04/2014. Date of Peer Review: 31/04/2014. Date of Acceptance: 09/06/2014. Date of Publishing: 16/06/2014. 